\title{
Differencial proteome of clear-cell renal cell carcinoma (ccRCC) tissues
}

Ana Júlia Vieira de Ribeiro, Vanessa Sandim, Antonio Augusto Ornellas, Rodrigo Siqueira Reis, Gilberto Domont, Gilda Alves

Applied Genetic Laboratory, Hematology Division, National Institute of Cancer (AJVR, VS, GA); Division of Urology, National Institute of Cancer, (AAO); Division of Urology, Hospital Mário Kroeff, (AAO); Proteomic Unit, Chemical Institute, Federal University of Rio de Janeiro, (RSR,GD), RJ, Brazil

\section{ABSTRACT}

Purpose: We attempted to detect, for the first time in a Brazilian cohort, differences in protein expression between clear-cell renal cell carcinoma (ccRCC) and their normal adjacent tissues, aiming to identify biomarkers and/or therapeutic target candidates for this disease.

Material and Methods: Twenty-four ccRCC and adjacent normal tissues were collected after surgery and their protein extracts were quantified, pooled and separated by two-dimensional polyacrylamide gel electrophoresis (2DE), followed by statistical analysis of the stained gels. Spots of interest were excised from the gels, digested with trypsin and identified by MALDI-TOF-TOF mass spectrometry.

Results: Twenty-six differential spots were detected between the two classes of tissues, among which twenty were identified by mass spectrometry and sixteen were found to be non-redundant. Eleven proteins were either underexpressed or undetected in the ccRCC extracts, such as prohibitin and peroxiredoxin-3, whereas five were found to be overexpressed or exclusively detected in the ccRCC extract, including $\alpha \beta$ crystalin and heat shock protein 27.

Conclusions: Several proteins were detected at differential levels when compared to normal adjacent tissues, and, moreover, many have been previously described by their relationship with RCC. Therefore, this work corroborates previous reports on the search for biomarkers for ccRCC, as well as it points out new candidates that may be validated in future studies.

\section{ARTICLE INFO}

\section{Key words:}

Carcinoma, Renal Cell;

Proteome; Electrophoresis,

Polyacrylamide Gel; Kidney

Int Braz J Urol. 2013; 39: 83-94

Submitted for publication:

May 29, 2012

Accepted after revision:

October 12, 2012

\section{INTRODUCTION}

Renal cell carcinoma (RCC) is the third most common cancer of the genitourinary system and represents approximately 3\% of adult malignancies in Western countries. It is the most prevalent malignancy of the kidney, accounting for about $85 \%$ of kidney cancers, as well as the most lethal of all urologic cancers. The most common histological subtype is the clear-cell renal cell carcinoma (ccRCC), corresponding to $70 \%$ of all RCC (1). Whereas the estimated annual incidence is about 54,000 new cases and 13,000 deaths from this disease in the United States (2), reliable estimates of this cancer in Brazil are missing.

Cancer markers can be used for early detection of disease in asymptomatic patients, for the assessment and management of the disease in its 
different phases, as well as for predicting its prognosis. A constant effort has been made (3-8) in the search for biomarker candidates for RCC. However, none of them achieved definitive diagnostic and prognostic value in clinical practice so far.

Reproducible protein profiles can hardly be obtained when different assays or different patient populations are used. Therefore, in order to ensure that a putative biomarker is robust enough for detection in different laboratories, validation with an independent sample set originating from a different institute is essential (9).

Proteomics is a promising tool for the better understanding of the biology of RCC and the search for proteins that can be used as markers of disease, as it provides a comprehensive view of cellular processes. Therefore, in this study we attempted to identify, for the first time within a Brazilian cohort, the differences in protein profiles of ccRCC tissues when compared to adjacent normal renal tissues, aiming to expand and/or access the validity of the putative biomarkers and therapeutic targets for ccRCC.

\section{MATERIAL AND METHODS}

\section{Patients}

A total of 24 ccRCC samples and their adjacent normal renal tissues were collected after radical nephrectomy at the Division of Urology of the National Institute of Cancer (Instituto Nacional do Câncer (INCA)) and Hospital Mário Kröeff (MK), Rio de Janeiro, Brazil, between 2005 and 2008 after approval by the INCA Ethical Committee with the number 38/05. Classification was according to the World Health Organization (WHO). Of the total of 24 patients 22 were operated in the Instituto Nacional do Cancer (INCA) and 2 at the Division of Urology in the Hospital Mário Kroeff. Patients included in the study were over 18 years, any gender, smokers and non-smokers. Patient with genetic syndromes, HIV infection, mental illness or previously treated for cancer were excluded. The cohort was composed of 14 males and 10 females. Their ages ranged from 28 to 80 years; mean age was 57 with standard deviation of 13.4. In our cohort of 24 tumors analysed, 14 (58\%) tumors were confined to the kidney. These and other clinical data of patients are shown in Table-1.
Proteins extraction and quantification

Tumor and adjacent normal tissues were collected by a pathologist immediately after surgery. Approximately $100 \mathrm{mg}$ of tissues were immersed in liquid nitrogen and macerated in the presence of $500 \mu \mathrm{L}$ lysis buffer, containing $7 \mathrm{M}$ urea, 2M thiourea, 4\% w/v 3-[(3-cholamidopropyl) dimethylammonio]-1-propanesulfonate (CHAPS) and 1\% w/v dithiothreitol (DTT). The mixture was agitated for 1 hour at room temperature and centrifuged at $16,000 \mathrm{~g}$ for 10 minutes. The supernatant containing proteins were collected and quantified using the kit 2D quant (GE Healthcare, Piscataway, USA).

\section{Two-dimensional Gel (2DE)}

After precipitation with trichloroacetic acid, proteins were resuspended in reswelling buffer $(4 \% \mathrm{w} / \mathrm{v}$ CHAPS, 8M urea, 1\% w/v DTT, $0.002 \% \mathrm{w} / \mathrm{v}$ bromophenol blue). For isoeletric focusing, a total of $1.5 \mathrm{mg}$ of proteins was applied on $18 \mathrm{~cm}$ strips of linear $\mathrm{pH}$ 3-10 (10). Four replicates were made for the each pool of sample. The platform used for separation was Ettan IPGphor ${ }^{\mathrm{TM}}$ (GE Healthcare, Piscataway, USA) at 30 volts for 12 hours at $20^{\circ} \mathrm{C}, 100$ volts for 1 hour, 200 volts for 1 hour, 500 volts for 1 hour, 1,000 volts for 1 hour, 1,000 to 8,000 volts for 0.5 hour and 8,000 volts up to 75,067 volts/hour.

After focusing, the strips were equilibrated and washed (10). The second dimension was performed in a SDS-PAGE gel $12.5 \%$. The run was made in the EttanTM system (GE Healthcare) with tris(hydroxymethyl)aminomethane (Tris) - glycine running buffer at $2.5 \mathrm{~W} /$ gel for $30 \mathrm{~min}$ and then $100 \mathrm{~W}$ until the end of the run. The gels were stained with Coomassie G-250 solution. Image and statistical analysis (Student's t test, p-value $<0.05$ ) of the stained gels were performed using Image Master 2D Platinum 5 (GE Healthcare, Piscataway, USA).

\section{Mass spectrometry}

Spots of interest were cut out from the gel and processed for in-gel digestion with trypsin. After digestion, peptides were extracted from gel in $30 \mu \mathrm{L}$ of a $5 \% \mathrm{v} / \mathrm{v}$ trifluoroacetic acid/ 50\% v/v acetonitrile solution and concen- 
Table 1 - Patient data, histopathological findings, tumor stage and survival analysis. Tumor Stage was accessed according to the TNM Classification of Malignant Tumors.

\begin{tabular}{|c|c|c|c|c|c|c|}
\hline Pts. & Age & Gender & Furhman Grade & Stage & Follow-up & $\begin{array}{l}\text { Deaths by } \\
\text { Disease }\end{array}$ \\
\hline 1 & 52 & Male & $\|$ & T1bNxM0 & 67 months & \\
\hline 2 & 56 & Male & I & T1aNxMx & 63 months & \\
\hline 3 & 44 & Male & II & T3aNxMx & 66 months & \\
\hline 4 & 58 & Female & ॥ & T1bNxMx & 65 months & \\
\hline 5 & 35 & Female & III & T2bNxMx & & 3 months \\
\hline 6 & 77 & Female & I & T3bN2Mx & 41 months & \\
\hline 7 & 54 & Female & 1 & T1bNxMx & 64 months & \\
\hline 8 & 80 & Male & ॥ & T1aNoMo & 64 months & \\
\hline 9 & 56 & Male & III & T3aNxMx & 64 months & \\
\hline 10 & 53 & Female & III & T1aNOMO & 63 months & \\
\hline 11 & 69 & Male & ॥ & T1aNxMx & 9 months & \\
\hline 12 & 33 & Female & I & T2aNxMx & 62 months & \\
\hline 13 & 45 & Female & II & T2bNxMx & 62 months & \\
\hline 14 & 69 & Male & ॥ & T3aNxMx & 61 months & \\
\hline 15 & 61 & Male & ॥ & T3aNxMx & 61 months & \\
\hline 16 & 75 & Female & ॥ & T1bNxMx & 60 months & \\
\hline 17 & 48 & Female & $\|$ & T1aNxMx & 59 months & \\
\hline 18 & 60 & Male & III & T4NXMx & & 57 months \\
\hline 19 & 66 & Male & III & T3aNxMx & 15 months & \\
\hline 20 & 55 & Male & III & T2NxMx & 54 months & \\
\hline 21 & 62 & Male & III & T3bNOMx & & 22 months \\
\hline 22 & 63 & Female & ॥ & T1bNxMx & 54 months & \\
\hline 23 & 58 & Male & III & T3aNxMx & 53 months & \\
\hline 24 & 28 & Male & III & T3aN2Mx & & 2 months \\
\hline
\end{tabular}


trated to final volume of $5 \mu \mathrm{L}$. MALDI analysis used $0.5 \mu \mathrm{L}$ of each peptide solution mixed with the same volume of a saturated matrix solution ( $\alpha$-cyano-4-hydroxycinnamic acid (Sigma Aldrich, Milwaukee, USA) at $0.05 \mathrm{M}$ in 50\% acetonitrile/ $0.1 \%$ trifluoroacetic acid) on the target plate and allowed to dry at room temperature. Data for protein identification were obtained on the 4700 Proteomics Analyzer (Applied Biosystems, Foster City, CA). Both MS and MS/MS data were acquired with a neodymium-doped yttrium aluminum garnet (Nd:YAG) laser with a $200-\mathrm{Hz}$ repetition rate. Typically, 1600 shots were accumulated for spectra in MS mode while 2400 shots were accumulated for spectra in MS/MS mode. MS and MS/ MS mass spectra were acquired in reflector positive ion mode after calibration with mixtures 1 or 2 (Sequazyme Peptide Mass Standard, Perseptive Biosystems, Foster City, CA). Proteins were identified by correlation of tandem mass spectra to the NCBInr proteins database, using Mascot (Matrix Science, London, UK) with restricted taxonomy Homo sapiens. Search parameters were as follows: MS and MS/MS tolerance of 0.6 Da, tryptic specificity allowing for one missed cleavage, fixed modification of carbamidomethylation of cysteine residues, and variable modification of oxidation of methionine, histidine and tryptophan residues; phosphorylation of tyrosine, serine and threonine residues and propionamide. Positive protein identification was accepted with at least two peptides with a Mascot peptide score $\geq 35$.

\section{RESULTS}

This study aimed to identify differentially expressed proteins in ccRCC tissues compared to their adjacent normal kidney tissues in 2DE gels. The patient cohort was composed of 14 males and 10 females. Their ages ranged from 28 to 80 years; mean age was 57 with standard deviation of 13.4.

Figure-1 shows the representative 2DE gel profiles of the experimental replicates of the two protein pools (tumor and adjacent normal tissues). The gels were analyzed by Image Master 2D Platinum software. The volumes of the spots were compared between the gels. Twenty six spots were identified as differentially expressed between
Figure 1 - (A) Normal kidney tissue, (B) ccRCC tissue. The gels were stained with colloidal Coomassie. $1.5 \mathrm{mg}$ of protein from pools of extracts was applied to the 2DE. First dimension was carried out with $18 \mathrm{~cm}$ IPG strips, pH 3-10; Second dimension was carried out in $12.5 \%$ SDS-PAGE.
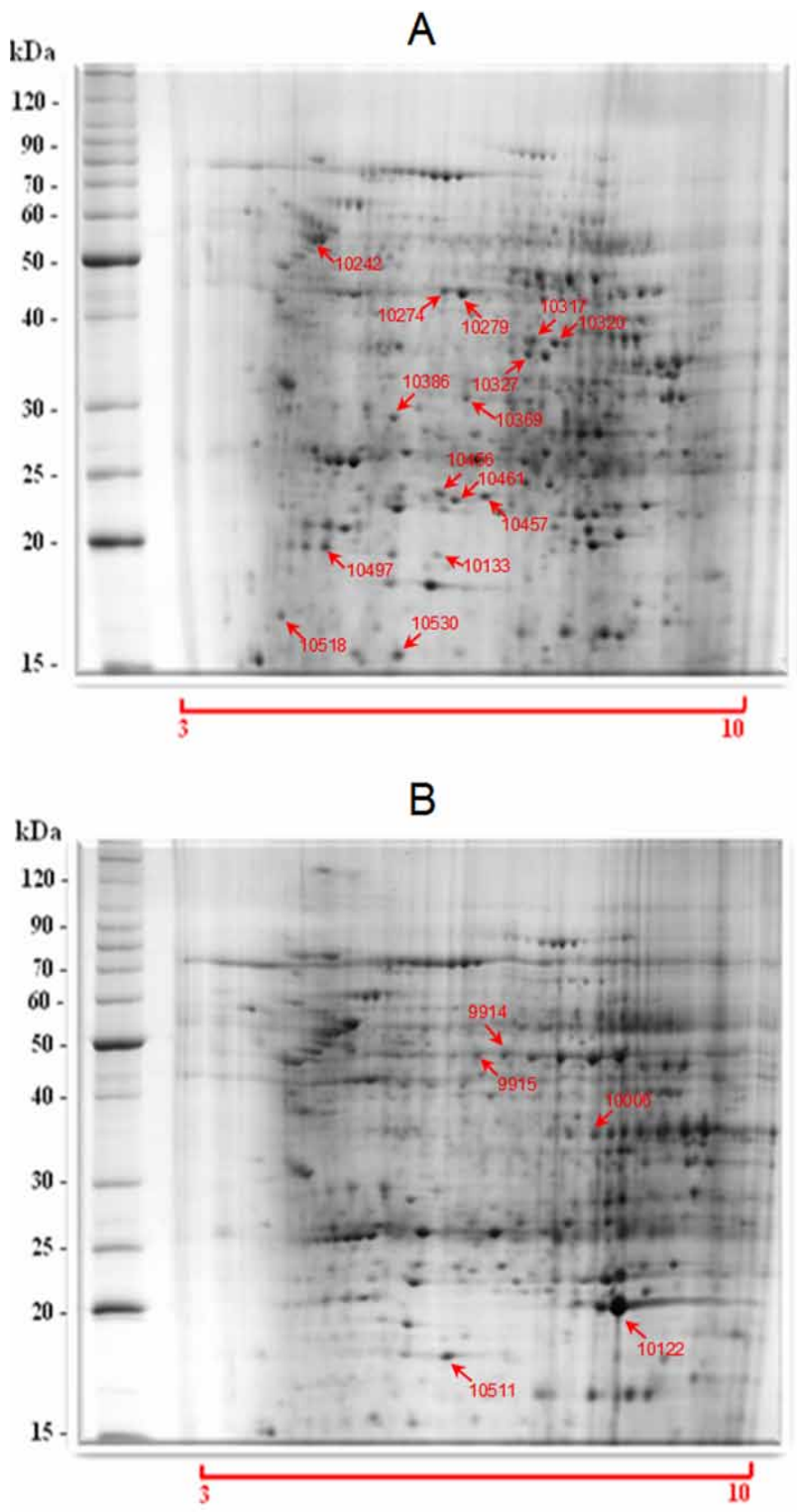

them, among which 20 were identified as 16 non-redundant proteins (Table-2).

Protein down-regulation was more frequent in the ccRCC proteome. Eleven proteins were either underexpressed or undetected in the ccRCC extracts: ATP synthase beta subunit, transthyretin chain A, peroxiredoxin 3, aminoacylase-1, aldehyde reductase, prohibitin, ferritin, abhydrolase, 


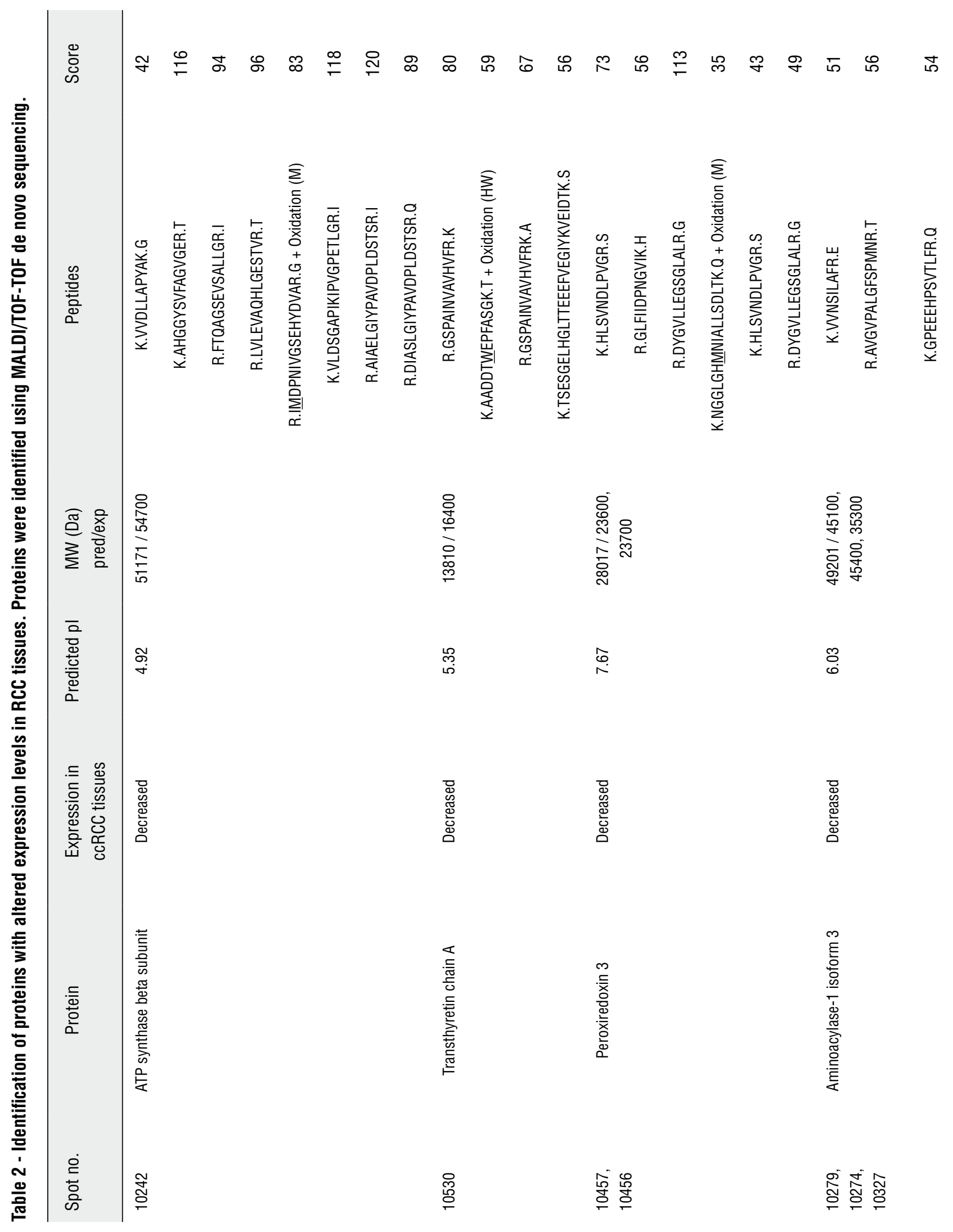


导 守
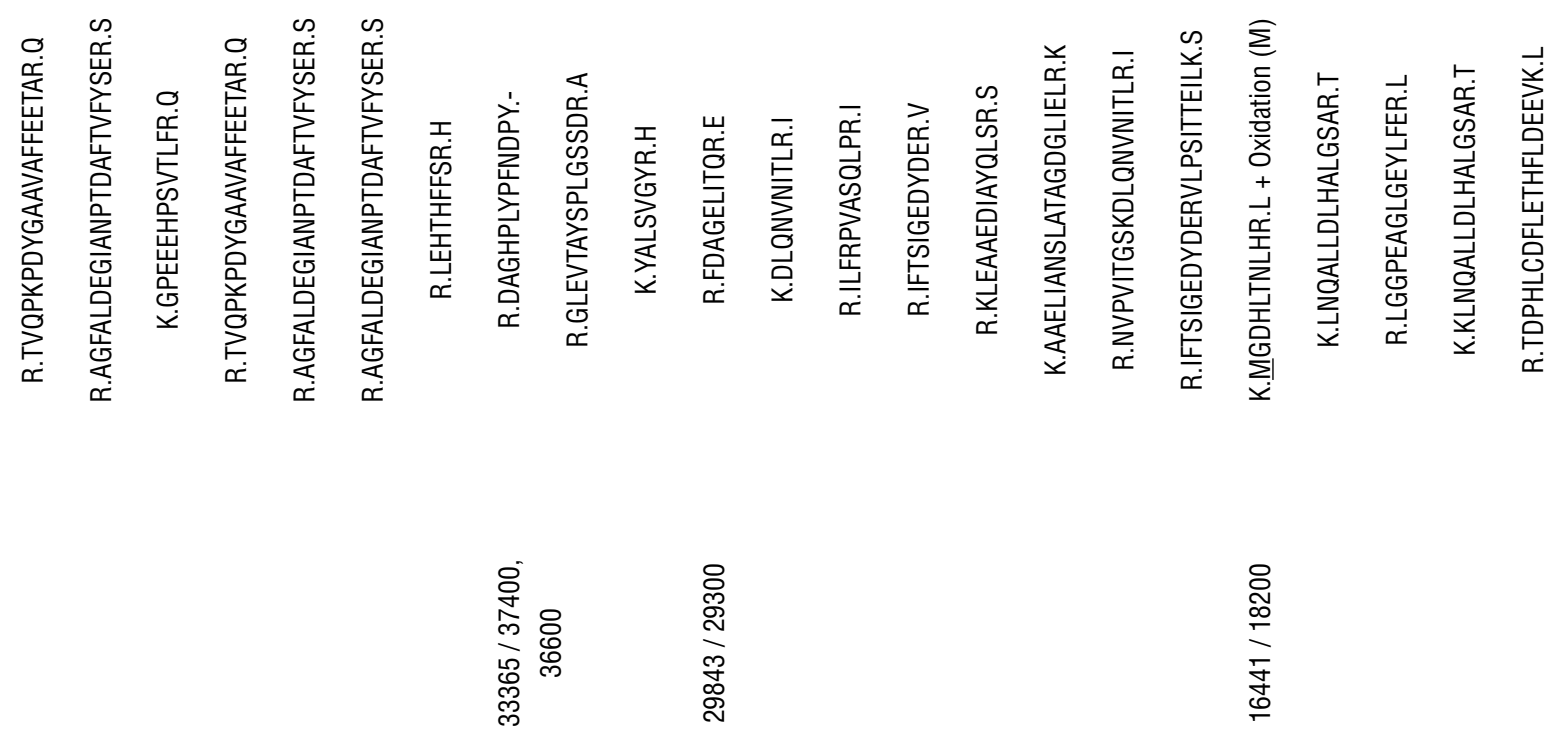

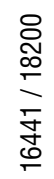

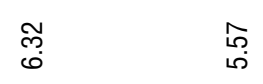

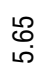

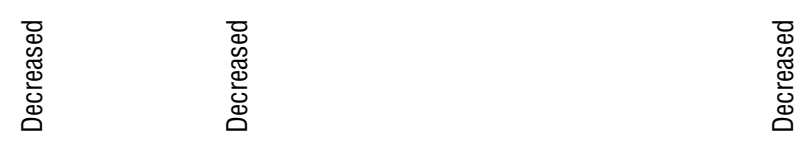

0
0
$\frac{\pi}{0}$
0
$\frac{0}{0}$
$\frac{0}{0}$
$\stackrel{0}{0}$
$\frac{0}{0}$

흘

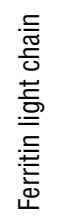

스융

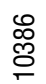

$\stackrel{m}{\stackrel{m}{0}}$ 


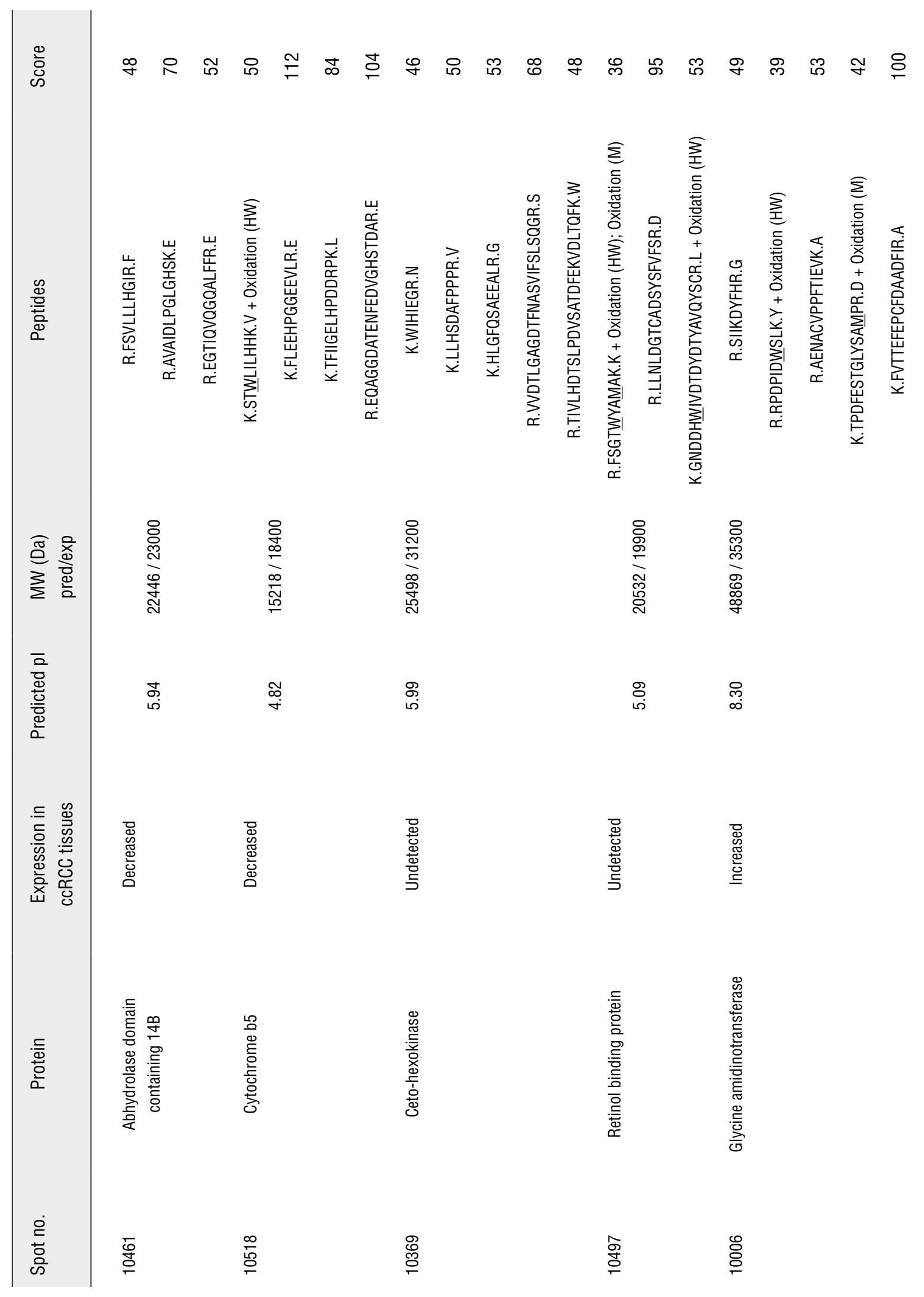


员

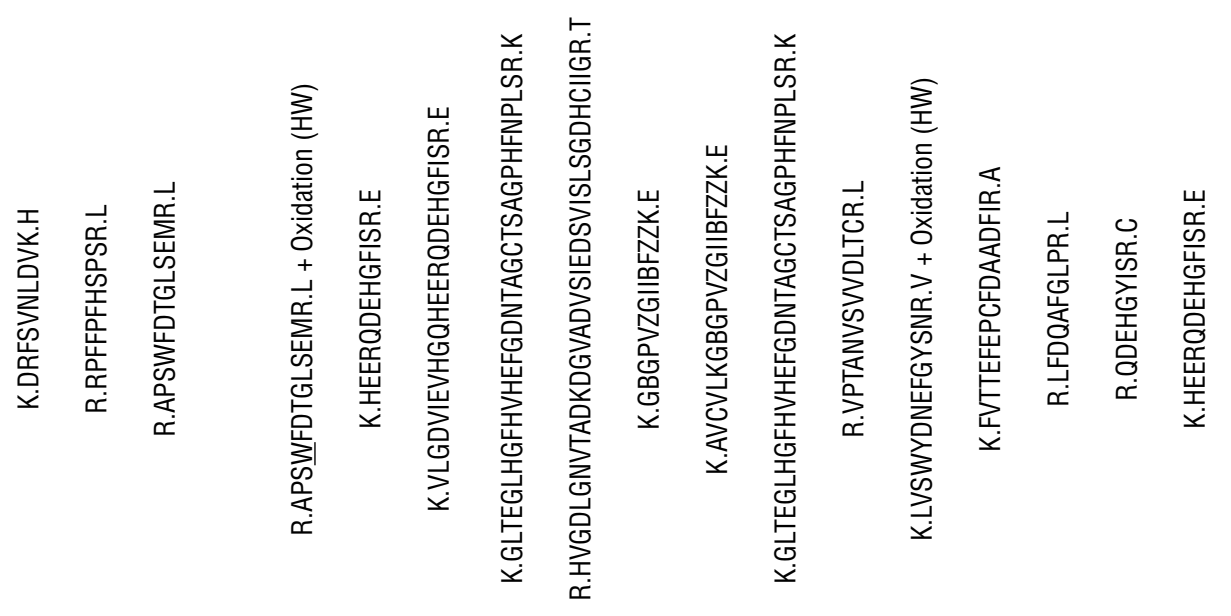

号

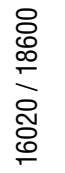

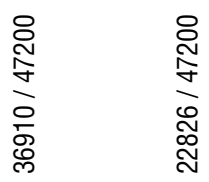

$\stackrel{\infty}{\sim}$

$\underset{\infty}{\infty}$

$\stackrel{Ð}{i}$

$\stackrel{\infty}{\infty}$

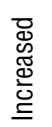

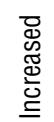

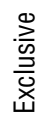

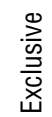

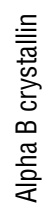
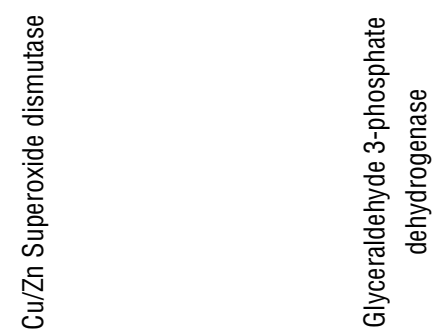

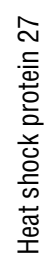

ิㅡㅁ

훙

흄

용 
cytochrome b5, ceto-hexokinase and retinol binding protein (Table-2).

On the other hand, five proteins were found to be either overexpressed or exclusively detected in the ccRCC extracts: glycine amidinotransferase, alpha B crystallin, $\mathrm{Cu} / \mathrm{Zn}$ superoxide dismutase, glyceraldehyde 3-phosphate dehydrogenase and heat shock protein 27 (HSP27) (Table-2).

\section{DISCUSSION}

The search for the ideal set of protein markers of RCC tissues began when Sarto et al. (3) compared the tumor proteins from 10 patients with ccRCC with their respective adjacent normal tissue through 2DE gel. Since then, other studies were performed with the same goal under different conditions or different proteomics approaches (38). The method that was applied in this study is based on 2DE, the most traditional technology for separation of proteins. It is a very efficient method, allowing good resolution of complex samples, providing the molecular weight and $\mathrm{pH}$ of the analyzed protein that, in certain instances, generates information about post-translational modifications. This work is justified by the fact that no study with RCC Brazilian patients was ever produced.

Some of the proteins here identified are involved in cellular metabolism, such as the beta subunit of ATP synthase, glycine amidinotransferase, cytochrome b5, glyceraldehyde 3-phosphate dehydrogenase, aminoacilase isoform 3, aldehyde reductase and ceto-reductase hexokinase.

The ATP synthase protein complex is directly involved in ATP production through oxidative phosphorylation in mitochondria, and is a high-energy molecule used in several metabolic processes (11). Glycine amidinotransferase enzyme participates in the metabolism of amino acids as well as in the urea cycle, and is found in all tissues of the body (11). Cytochrome b5 is a protein that participates in the desaturation of fatty acids and was described to be underexpressed in RCC (8). Glyceraldehyde-3 phosphate dehydrogenase (GAPDH) participates in the oxidation of glyceraldehyde 3-phosphate, associated with the formation of ATP molecules in the electron trans- port chain in mitochondria (11). GAPDH was exclusively detected in the ccRCC extract. GAPDH is a constitutive enzyme and therefore it is likely to be present in the normal extracts. Two hypotheses may explain our results: GAPDH is undergoing posttranslational modifications and/or degradation in the normal tissue or GAPDH is modified and accumulates at detectable levels in the ccRCC tissue, whereas in the normal tissue it is present at undetectable levels. Previous works suggest that GAPDH is indeed target of modifications that can modulate its cellular level $(12,13)$.

Aminoacylase-I is a homodimeric cytosolic enzyme that catalyzes the hydrolysis of a variety of $\mathrm{N}$-acylated amino acids, generating free amino acids and acyl groups. The enzyme is found in many mammalian tissues, with highest activity in the kidney, and is involved in detoxification processes. Balabanov et al (11) and Raimondo et al (8) observed underexpression of aminoacylase-I when they analyzed the proteome of ccRCC tissues. An interesting fact is that the gene enconding for this enzyme is located on chromosome $3 \mathrm{p} 21-1$, and deletions in the short arm of chromosome 3 were observed in almost all renal cell carcinomas.

Ketohexokinase, also known as fructokinase, participates in the metabolism of fructose, catalyzing the conversion of fructose to fructose-1-phosphate. Although the ketohexokinase is mostly abundant in liver, it was also found in kidney, small intestine and pancreas (4). Hwa et al (4) found lower levels of ketohexokinase in ccRCC tissues, in accordance with our findings.

Aldehyde reductase is an oxidoreductase that catalyzes NADPH-dependent reduction of a variety of aliphatic and aromatic aldehydes. However, little is known about its physiological role. We observed underexpression of aldehyde reductase in agreement with previous published data on RCC (4).

Peroxiredoxins (Prxs) are a family of proteins whose members were originally identified as thiol-specific antioxidant enzymes (14). They act as regulatory signals mediated by $\mathrm{H}_{2} \mathrm{O}_{2}$. Peroxirredoxin-3 (PRX-3), identified in this work as underexpressed, is known to regulate the levels of $\mathrm{H}_{2} \mathrm{O}_{2}$ and its effects. Oxidative stress plays a crucial role in the pathogenesis of various malignancies. It is 
possible that carcinogenesis by oxidative stress is mainly due to excessive production of reactive oxygen species (ROS) such as $\mathrm{H}_{2} \mathrm{O}_{2}$ and superoxide anion, leading to structural changes in DNA. Moreover, ROS can directly activate cytoplasmic and nuclear pathways of signal transduction that are associated with malignant transformation. Therefore, it is suggested that antioxidant enzymes, such as peroxiredoxins, play a functional role in carcinogenesis (15).

Soini et al (16) studied the expression of peroxiredoxins 1 to 6 in 138 RCC samples using immunohistochemistry and immunoblotting. The authors correlated the expression of peroxiredoxins with tumor stage and patient survival rate. Non-malignant tubular cells were positive for all six Prxs. Most RCC were positive for Prxs 1 and 2 , whereas only $15 \%$ of tumors showed expression of Prxs 3 and 4. In this study, lower levels of peroxirredoxin-3 were observed in ccRCC tissues extracts, which is consistent with data previously published (16).

The superoxide dismutases (SOD) are antioxidant enzymes that catalyze the dismutation of superoxide radicals into hydrogen peroxide and oxygen (17). We found overexpression of SOD-1 in ccRCC extracts. This can be explained by the fact that the production of ROS is generally more active in malignant cells (17).

Transthyretin acts as a carrier of retinol (vitamin A), through its association with retinol-binding protein (RBP). Retinol is a natural precursor of the retinoic acid, which regulates the transcription of specific genes through nuclear receptors of retinoic acid, having effects on cell growth and differentiation of normal cells, embryonic cells, as well as on neoplastic cells (18). We observed underexpression of transthyretin in the ccRCC extract, whereas RBP protein was not detected. Because the kidneys play a role in the metabolism of proteins of low molecular weight, such as RBP, it is possible that the disability of renal filtration that occurs in RCC leads to greater loss of circulating RBP. This, in turn, can result in decreasing levels of transthyretin.

Ferritin is the most important iron reserve protein and found in all cells. Under normal conditions, it can represent $25 \%$ of the total iron found in the body (19). Anemia is the most common hematologic abnormality associated with kidney cancer (1). This picture may be a consequence of bad function of iron storage proteins such as ferritin. Concurring with this, in the present study we observed lower levels of ferritin in ccRCC protein extracts.

The gene encoding prohibitin was first isolated due to its ability to down regulate rat hepatocytes cell proliferation (20). Its antiproliferative activity was further demonstrated when the micro-injection of synthetic mRNA in normal fibroblasts and HeLa cells blocked the entry of cells in S phase of the cell cycle (21). Furthermore, prohibitin is capable of inhibiting cell proliferation by repressing the transcriptional activity mediated by E2F which regulates many genes involved in the transition G1 / S and DNA synthesis (22). The study of Fusaro et al (23) has also shown that in addition to its mitochondrial localization, prohibitin is also located in the nucleus, and is able to physically interact with p53 in vivo and in vitro, potentially modulating their regulatory pathways. These data suggested that prohibitin is able to act as tumor suppressor. However, the role of prohibitin as tumor suppressor has been debated. Prohibitin undergoes multiple post-translational modifications, such as phosphorylation, glycosylation, palmitoylation, ubiquitination and others; therefore, it is reasonable to propose more than one function for prohibitin. In fact, the presence of isoforms could explain the shift in molecular weight of the two prohibitin spots that were observed on RCC gels (24). In addition, prohibitin was recently found to combat oxidative stress, as well as to have a role in modulating mitochondrial stress-related autophagy (25). We found underexpression of prohibitin in ccRCC extracts, which is consistent with its apparent tumor suppressor function and free radical protection.

The heat shock proteins (HSP) are a group of stress-inducible molecules. Members of this family include $\alpha \beta$-crystalin and HSP27. Several evidences suggest that HSP27 and $\alpha \beta$-crystalin are associated in the cells (26). We detected higher expression of $\alpha \beta$ crystalin in ccRCC extracts what is accordance with previous papers $(7,27,28)$. Normally, $\alpha \beta$-crystalin is a major protein compo- 
nent of the vertebrate eye lens with chaperone-like functions. It is probable the up-expression of $\alpha \beta$-crystalin represents a response to stress.

Previous studies have shown higher expression of HSP27 in ccRCC (27,29-32). We observed the same result. HSP27 down-regulates apoptosis through its ability to interact with key components of the apoptosis signaling pathway, in particular those involved in activation of caspases. Because of this physiologic effect, it is likely that HSP27 is involved in cell proliferation of ccRCC.

\section{CONCLUSIONS}

Our results present the first proteomics analysis of ccRCC tissues within a Brazilian population. Several proteins were found at differential levels when compared to their normal adjacent tissues and, moreover, many have been previously described in studies on RCC, when other populations were used. Therefore, this work accesses the robustness and validity of previously reported proteins and points out candidate biomarkers and/or targets for RCC that may be validated in future trials.

\section{ACKNOWLEDGEMENTS}

This work was supported by Programa de Oncobiologia (Rio de Janeiro, Brazil), the Carlos Chagas Foundation for the Support of Science (FAPERJ) and the Conselho Nacional de Desenvolvimento Científico e Tecnológico (CNPq), Brazil.

\section{CONFLICT OF INTEREST}

None declared.

\section{REFERENCES}

1. Campbell SC, Novick AC. Renal Tumors. In: Walsh PC, Retik AB, Vaughan ED, Wein AJ (Editors), Kavoussi LR, Novick AC, Partin AW, Peters CA (ed.), Campbell's Urology, Philadelphia, Elsevier, 2002; pp. 2672-86.

2. Ries LA, Melbert D, Krapcho M, Stinchcomb DG, Howlader N, Horner MJ, et al.: (ed.), SEER Cancer Statistics Review, 1975-2005, National Cancer Institute. Bethesda, MD, http:// seer.cancer.gov/csr/1975_2005/, based on November 2007 SEER data submission, posted to the SEER website, 2008.
3. Sarto C, Marocchi A, Sanchez JC, Giannone D, Frutiger S, Golaz 0, et al.: Renal cell carcinoma and normal kidney protein expression. Electrophoresis. 1997; 18: 599-604.

4. Hwa JS, Park HJ, Jung JH, Kam SC, Park HC, Kim CW, et al.: Identification of proteins differentially expressed in the conventional renal cell carcinoma by proteomic analysis. J Korean Med Sci. 2005; 20: 450-5.

5. Perroud B, Lee J, Valkova N, Dhirapong A, Lin PY, Fiehn O, et al.: Pathway analysis of kidney cancer using proteomics and metabolic profiling. Mol Cancer. 2006; 5: 64.

6. Jones J, Otu HH, Grall F, Spentzos D, Can H, Aivado M, et al.: Proteomic identification of interleukin-2 therapy response in metastatic renal cell cancer. J Urol. 2008; 179: 730-6.

7. Siu KW, DeSouza LV, Scorilas A, Romaschin AD, Honey RJ, Stewart $\mathrm{R}$, et al.: Differential protein expressions in renal cell carcinoma: new biomarker discovery by mass spectrometry. J Proteome Res. 2009; 8: 3797-807.

8. Raimondo F, Salemi C, Chinello C, Fumagalli D, Morosi L, Rocco F, et al.: Proteomic analysis in clear cell renal cell carcinoma: identification of differentially expressed protein by 2-D DIGE. Mol Biosyst. 2012; 8: 1040-51.

9. Engwegen JY, Mehra N, Haanen JB, Bonfrer JM, Schellens $\mathrm{JH}$, Voest EE, e al.: Validation of SELDI-TOF MS serum protein profiles for renal cell carcinoma in new populations. Lab Invest. 2007; 87: 161-72.

10. Görg A, Weiss W, Dunn MJ: Current two-dimensional electrophoresis technology for proteomics. Proteomics. 2004; 4: 3665-85. Erratum in: Proteomics. 2005; 5: 826-7.

11. Balabanov S, Zimmermann U, Protzel C, Scharf C, Klebingat KJ, Walther R: Tumour-related enzyme alterations in the clear cell type of human renal cell carcinoma identified by two-dimensional gel electrophoresis. Eur J Biochem. 2001; 268: 5977-80.

12. Pierce A, Mirzaei $H$, Muller F, De Waal E, Taylor AB, Leonard $S$, et al.: GAPDH is conformationally and functionally altered in association with oxidative stress in mouse models of amyotrophic lateral sclerosis. J Mol Biol. 2008; 382: 1195-210.

13. Mazzola JL, Sirover MA: Alteration of intracellular structure and function of glyceraldehyde-3-phosphate dehydrogenase: a common phenotype of neurodegenerative disorders? Neurotoxicology. 2002; 23: 603-9.

14. Immenschuh S, Baumgart-Vogt E: Peroxiredoxins, oxidative stress, and cell proliferation. Antioxid Redox Signal. 2005; 7: 768-77.

15. Nonn L, Berggren M, Powis G: Increased expression of mitochondrial peroxiredoxin-3 (thioredoxin peroxidase-2) protects cancer cells against hypoxia and drug-induced hydrogen peroxide-dependent apoptosis. Mol Cancer Res. 2003; 1 : 682-9.

16. Soini $Y$, Kallio JP, Hirvikoski $P$, Helin $H$, Kellokumpu-Lehtinen $P$, Kang SW, et al.: Oxidative/nitrosative stress and peroxiredoxin 2 are associated with grade and prognosis of human renal carcinoma. APMIS. 2006; 114: 329-37. 
17. Hileman EO, Liu J, Albitar M, Keating MJ, Huang P: Intrinsic oxidative stress in cancer cells: a biochemical basis for therapeutic selectivity. Cancer Chemother Pharmacol. 2004; 53: 209-19.

18. Soprano DR, Soprano KJ, Goodman DS: Retinol-binding protein messenger RNA levels in the liver and in extrahepatic tissues of the rat. J Lipid Res. 1986; 27: 166-71.

19. Park KS, Kim H, Kim NG, Cho SY, Choi KH, Seong JK, et al.: Proteomic analysis and molecular characterization of tissue ferritin light chain in hepatocellular carcinoma. Hepatology. 2002; 35: 1459-66.

20. McClung JK, Danner DB, Stewart DA, Smith JR, Schneider EL, Lumpkin CK, et al.: Isolation of a cDNA that hybrid selects antiproliferative mRNA from rat liver. Biochem Biophys Res Commun. 1989; 164: 1316-22.

21. Nuell MJ, Stewart DA, Walker L, Friedman V, Wood CM, Owens GA, et al.: Prohibitin, an evolutionarily conserved intracellular protein that blocks DNA synthesis in normal fibroblasts and HeLa cells. Mol Cell Biol. 1991; 11: 1372-81.

22. Wang S, Nath N, Adlam M, Chellappan S: Prohibitin, a potential tumor suppressor, interacts with RB and regulates E2F function. Wang S, Nath N, Adlam M, Chellappan S. Oncogene. 1999; 18: 3501-10.

23. Fusaro G, Dasgupta P, Rastogi S, Joshi B, Chellappan S: Prohibitin induces the transcriptional activity of p53 and is exported from the nucleus upon apoptotic signaling. J Biol Chem. 2003; 278: 47853-61.

24. Junker H, Venz S, Zimmermann U, Thiele A, Scharf C, Walther R: Stage-related alterations in renal cell carcinoma-comprehensive quantitative analysis by 2D-DIGE and protein network analysis. PLoS One. 2011; 6: e21867.

25. Kathiria AS, Butcher LD, Feagins LA, Souza RF, Boland CR, Theiss AL: Prohibitin 1 modulates mitochondrial stressrelated autophagy in human colonic epithelial cells. PLoS One. 2012; 7: e31231.
26. Takashi M, Sakata T, Ohmura M, Kato K: Elevated concentrations of the small stress protein HSP27 in rat renal tumors. Urol Res. 1997; 25: 173-7.

27. Shi T, Dong F, Liou LS, Duan ZH, Novick AC, DiDonato JÁ: Differential protein profiling in renal-cell carcinoma. Mol Carcinog. 2004; 40: 47-61.

28. Holcakova J, Hernychova L, Bouchal P, Brozkova K, Zaloudik J, Valik D, et al.: Identification of alphaB-crystallin, a biomarker of renal cell carcinoma by SELDI-TOF MS. Int J Biol Markers. 2008; 23: 48-53.

29. Santarosa M, Favaro D, Quaia M, Galligioni E: Expression of heat shock protein 72 in renal cell carcinoma: possible role and prognostic implications in cancer patients. Eur $\mathrm{J}$ Cancer. 1997; 33: 873-7.

30. Erkizan 0, Kirkali G, Yörükoğlu K, Kirkali Z: Significance of heat shock protein-27 expression in patients with renal cell carcinoma. Urology. 2004; 64: 474-8.

31. Sarto C, Valsecchi C, Magni F, Tremolada L, Arizzi C, Cordani $\mathrm{N}$, et al.: Expression of heat shock protein 27 in human renal cell carcinoma. Proteomics. 2004: 2252-60.

32. Kim DS, Choi YP, Kang S, Gao MQ, Kim B, Park HR, et al.: Panel of candidate biomarkers for renal cell carcinoma. J Proteome Res. 2010; 9: 3710-9.
Correspondence address:

Dr. Antonio Augusto Ornellas Department of Urology Instituto Nacional de Câncer Praça da Cruz Vermelha, 23 Rio de Janeiro, RJ, 20230-130, Brasil E-mail: ornellasa@hotmail.com 